\title{
NICOTINIC ACETYLCHOLINE RECEPTORS: SPECIFIC ANTIBODIES AND FUNCTIONS IN HUMORAL IMMUNITY
}

\author{
M. V. SKOK, L. M. KOVAL, O. Yu. LYKHMUS, O. M. KALASHNYK, \\ G. L. GERGALOVA, S. V. KOMISARENKO \\ Palladin Institute of Biochemistry, National Academy of Sciences of Ukraine, Kyiv; \\ e-mail: skok@biochem.kiev.ua
}

\begin{abstract}
Nicotinic acetylcholine receptors ( $\mathrm{nAChRs)}$ ) are ligand-gated ion channels initially discovered in muscles and neurons and further found in many non-excitable cells. The present review summarizes the results of studies performed in the Department of Molecular Immunology during the last decade and concerning the structure and functions of $n A C h R s$ in B lymphocytes and in mitochondria, as well as the role of $n A C h R$-specific antibodies in the development of neurodegenerative disorders like Alzheimer disease.
\end{abstract}

Key words: nicotinic acetylcholine receptors, B lymphocytes, mitochondria, antibodies, Alzheimer's disease.

A cetylcholine (ACh) is an evolutionary ancient mediator, which, in addition to its functions as a neurotransmitter, regulates vital cellular processes like proliferation, survival, adhesion and motility. Consequently, receptors to ACh of both nicotinic and muscarinic type initially studied in excitable nerve and muscle cells, are now being found in numerous animal tissues, [1-3], and their prototypes have been recently reported in bacteria [4].

Nicotinic acetylcholine receptors (nAChRs) are ligand-gated ion channels discovered in the neuromuscular junctions and fish electric organs and further found in the central and autonomic nervous system, as well as in many non-excitable cells [5]. Structurally, they are either homo- or heteropentamers composed of various combinations of structurally homologous subunits. Muscular receptors are composed of $(\alpha 1)_{2} \beta 1 \gamma \delta(\varepsilon)$ subunits and are similar in all parts of the body. Neuronal type nAChRs, which are also expressed in nonexcitable cells, are much more heterogeneous: they consist of $\alpha 2-\alpha 10$ and $\beta 2-\beta 4$ subunits combined either as homomers $(\alpha 7, \alpha 8, \alpha 9)$ or heteromers $(\alpha 3 \beta 2$, $\alpha 3(\alpha 5) \beta 4, \alpha 4 \beta 2$, etc; reviewed in [6]). Homomeric a7 nAChRs are considered to be the most evolutionary ancient; they are found in both neurons and non-excitable cells to control the cell viability [7]; motility [8], as well as angiogenesis [9] and inflammation [10].

The nAChRs were considered related to immune processes when it was found that muscular dystrophy Myasthenia gravis can be caused by autoantibodies against muscular nicotinic receptor [11]. Further, the antibodies specific to different $\mathrm{nAChR}$ epitopes were generated artificial- ly as the tools to study the subunit composition and functions of nicotinic receptors expressed in various animal tissues. In particular, muscular type nAChRs were found in the thymus and were considered as possible immunogens stimulating autoantibody production upon autoimmune myasthenia [12]. In parallel, nicotinic receptors in immune cells attracted attention as potential targets of nicotine causing immunosuppressive effects on both the cellular and humoral immunity in smokers [13]. However, the main efforts were directed to study the expression and role of nAChRs in $\mathrm{T}$ lymphocytes, whereas those expressed in $\mathrm{B}$ lymphocytes were obviously underestimated. The studies performed in the Department of Molecular Immunology, Palladin Institute of Biochemistry, during the last decade were aimed to fill this gap by investigating the subunit composition, role and mechanisms of functioning of $\mathrm{nAChRs}$ expressed in B lymphocytes.

\section{Generation of antibodies against nAChR subunits}

The first step to achieve this goal was creating the instruments capable to target specific nAChR subtypes in B lymphocytes. For this purpose, we generated a panel of both polyclonal and monoclonal antibodies against extracellular epitopes of $\alpha 3, \alpha 4, \alpha 5, \alpha 7, \beta 2$ and $\beta 4$ nAChR subunits. The antibodies were directed against synthetic peptides corresponding to the fragments of alpha ( $\alpha 3(181-$ 192), $\alpha 4(181-192), \alpha 5(180-191), \alpha 7(179-190))$ or beta ( $\beta 2(190-200), \beta 4(190-200))$ subunits either participating directly or located closely to the acetylcholine-binding site [6]. The peptides were synthesized in Hellenic Pasteur Institute, Athens, Greece (the 
group of Prof. S. Tzartos) and in ShemyakinOvchinnikov Institute of Bioorganic Chemistry, Moscow, Russian Federation (Prof. V. Tsetlin). Since the peptides were quite different in amino acid composition, the resulting antibodies were assumed to distinguish between homologous subunits and to selectively influence the functions of certain nAChR subtypes. The specificity and functional properties of these antibodies were tested in the established cell lines and in the neurons of several autonomic ganglia expressing corresponding nAChRs by means of immunocytochemistry, immunoenzyme techniques like Western blots and Cell ELISA, fluorescent flow cytometry and electrophysiology approaches to study both acetylcholine-induced membrane currents and excitatory post-synaptic potentials (EPSP) [14-16]. It was demonstrated that the antibodies were both subunit-specific and functionally potent: they blocked membrane currents induced by externally applied acetylcholine [14], as well as electric potentials stimulated through excitation of nerve endings [15]. These studies were performed in collaboration with the laboratory of Prof. V. Skok in Bogomoletz Institute of Physiology, Kyiv. One of these antibodies (mAb 1D6, a3(181-192)-specific) was used to explore the structure of corresponding epitope within the native nAChR molecule. By means of NMR it was shown that mAb 1D6, which effectively bound native $\alpha 3$-containing $\mathrm{nAChRs}$ in flow cytometry, stabilized $\alpha 3(181-192)$ peptide in an extended conformation suggesting its similar structure within the whole receptor molecule [17]. This work was performed in collaboration with Dr. M. Marraud from Ecole Polytechniques, Nancy, France. Antibody against $\alpha 9(11-23)$ fragment was obtained later and was tested immediately in B lymphocytes [18].

\section{Structure and functions of nAChRs in B lymphocytes}

Having proved the specificity of instruments (antibodies), we used them to screen the nAChRs expressed on the surface of normal mouse B lymphocytes and of several mouse and human cell lines of B lymphocyte origin. It was found that, in contrast to autonomic ganglia, which expressed mainly $\alpha 3(\alpha 5) \beta 4$ and $\alpha 7 \mathrm{nAChRs,} \mathrm{B} \mathrm{lympho-}$ cytes exposed $\alpha 4(\alpha 5) \beta 2$, $\alpha 7$ - and $\alpha 9$-containing nAChR subtypes [18]. Their relative quantities were changed along with the B lymphocyte maturation: the immature newly generated $\mathrm{B}$ lymphocytes within the bone marrow expressed mainly a4 32 nAChRs, while the mature B lymphocytes in the periphery were mainly $\alpha 7$-positive [19]. $\alpha 9$ subunit was much less numerous, but its expression increased in the lymphocytes of $\alpha 7-/-$ mice indicating that it could compensate the absence of $\alpha 7$ subunit (this experiment was performed in collaboration with Prof. S. Grando from University of California, Irvine, USA) [18]. In addition, long-term exposure to nicotine resulted in the increase of surface nAChRs of both $\alpha 4 \beta 2$ and $\alpha 7$ subtypes, similarly to neuronal nAChRs in the brain, which were shown to be up-regulated in smokers or experimental animals exposed to nicotine [20]. The relative density of $\mathrm{nAChR}$ subtypes was different in mice of two strains, $\mathrm{C} 57 \mathrm{Bl} / 6$ and $\mathrm{BALB} / \mathrm{C}$, indicating that the expression levels of different $n A C h R$ subunits were genetically determined [18]. The binding of subunit-specific antibodies was verified and confirmed by the binding of $n A C h R$-specific radioligands, epibatidine and $\alpha$-bungarotoxin. Epibatidine binds heteromeric, mainly $\alpha 4 \beta 2$ nAChRs, while $\alpha$-bungarotoxin is specific for $\alpha 7$-containing nAChRs. We found that B lymphocyte-derived X63-Ag-8 myeloma cells expressed on average $10170 \pm 1100\left[{ }^{3} \mathrm{H}\right]$-Epibatidine (total) and $6730 \pm 370\left[{ }^{125} \mathrm{I}\right]-\alpha$-Bungarotoxin (surface) binding sites per cell, thus reflecting the presence of both homomeric and heteromeric nicotinic receptors [21]. Normal mouse B lymphocytes contained $12200 \pm 3200$ of epibatidine-binding sites and $3130 \pm 750$ of $\alpha$-Bungarotoxin-binding sites per cell [22].

The density of nAChRs on the surface of B lymphocytes increased not only upon their maturation, but also upon activation, both in vitro with anti-CD40 antibody and in vivo upon immunization with a protein antigen [23]. This data indicated that the nAChRs might be important for regulating B lymphocyte functions. We addressed this question by studying the effects of specific $n A C h R$ ligands on B lymphocyte proliferation and antibody production.

The first experiments were performed in mouse B lymphocyte-derived hybridoma cells [21]. It was found that nicotine stimulated hybridoma cell proliferation but decreased antibody production. In contrast, $\alpha 7$-specific snake toxins ( $\alpha$-cobratoxin and "weak" toxin) inhibited cell proliferation but increased antibody production. The snake toxins for these studies were obtained and provided to us by the group of Prof. V. Tsetlin.

To study the role of $n A C h R s$ in normal $B$ lymphocytes we employed several experimental approaches including the use of knockout mice lacking $\alpha 4, \alpha 7$ or $\beta 2 \mathrm{nAChR}$ subunits, as well as pharmacological instruments specific for different nAChR subtypes. These experiments were performed in collaboration with the laboratory of Prof. Jean-Pierre Changeux at Pasteur Institute in Paris. 
It was found that mice lacking $\mathrm{nAChR} \alpha 4$, $\beta 2$ or $\alpha 7$ subunits had less IgG in the blood and IgG-producing cells in the spleen, but showed stronger immune response to both protein antigen in vivo and CD40-specific antibody in vitro than the wild-type mice. These results indicated that signalling through nicotinic receptors affected both the pre-immune state and activation of B lymphocytes in the immune response, possibly via CD40dependent pathway [22].

To further address this question and to exclude a possible contribution of neuronal regulation to the development of immune cells, we created chimera mice, which lacked certain nAChR subunits (subtypes) in a fraction of immune cell precursors only and compared the propagation of either the wild-type or nAChR-deficient B lymphocytes in irradiated hosts [19]. It was found that bone marrow B lymphocytes lacking either $\beta 2$ or $\alpha 7 \mathrm{nAChR}$ subunits propagated much less efficiently than the wild-type cells bearing corresponding $\mathrm{nAChR}$ subtypes. Similar dependence was found for $\mathrm{T}$ lymphocytes developing within the thymus. In contrast, the propagation of both $\mathrm{B}$ and $\mathrm{T}$ lymphocytes in the spleen was dependent on the presence of $\alpha 7$ subunit only; moreover, the effect of the nAChR subunit presence or absence was observed only when mice consumed nicotine with the drinking water. These data confirmed our previously made observation on the differential expression of the two nAChR subtypes along with the B lymphocyte activation and on the pro-proliferative role of nicotine. They also indicated that the endogenous ligand for B lymphocyte-expressed nAChRs was present in the bone marrow and thymus, but not in the spleen. These experiments were performed in collaboration with Drs. R. Grailhe and F. Agenes from Pasteur Institute in Paris.

The observed effect of the nAChR subtype presence on the $\mathrm{T}$ lymphocyte development suggested a general role of cholinergic regulation in hematopoiesis. To study this question more in detail, we compared the numbers of different blood cells and their precursors within the bone marrow and spleen of either the wild-type mice or those lacking $\alpha 7$ or $\beta 2 \mathrm{nAChR}$ subunits. It was found that either the absence of $\alpha 7$-containing nicotinic receptors in knockout mice or their desensitization in mice chronically treated with nicotine decreased the number of myeloid and erythroid progenitors and junior cells. In contrast, the absence of $\beta 2$ containing receptors favored myelocyte generation and erythroid cell maturation. Both erythroid and myeloid progenitor cells bound more $\alpha 4$-specific antibody than their mature forms, while the binding of $\alpha$-cobratoxin and $\alpha 7$-specific antibody was also high in mature cells. It was concluded that the development of both myeloid and erythroid cell lineages is regulated by endogenous cholinergic ligands and can be affected by nicotine through $\alpha 7$ - and $\alpha 4 \beta 2$-containing nicotinic receptors, which play different roles in the course of these cells maturation [24]. This work was performed with the help of Dr. A. Zverkova from Hemathology and Transfusiology Institute, Kyiv.

Returning to B lymphocytes, we were further interested in the mechanism of the nAChRs involvement in regulating their activation in the immune response. To address this question, we investigated the localization of different $n A C h R$ subtypes on the B lymphocyte surface in relation to known B lymphocyte markers like B220 (CD45R), CD23, BCR (IgM), CD40 or Fc $\gamma R$ (CD16/32). B220 seemed to be non-related, since B lymphocyte purification with B220-coated magnetic beads did not affect the nAChR-specific antibody binding. Double staining of purified B lymphocytes with the fluorescently labeled anti-IgM, anti-CD23, anti-CD40 or anti-CD16/32 in the presence of unlabeled antibodies against various nAChR subunits demonstrated that the binding of anti-IgM and anti-CD23 was affected with the antibodies against $\alpha 4, \beta 2$ or $\beta 4$ subunits; the binding of anti-CD40 was affected with the antibodies against $\alpha 7$ or $\alpha 9$ subunits, and the binding of Fc $\gamma R$-specific antibody was not affected by the nAChR-specific antibodies. It was suggested that $\alpha 4 \beta 2(\beta 4)$ nAChRs were located close to BCR and CD23 on the B lymphocyte surface, while $\alpha 7$ and $\alpha 9$ nAChRs were close to CD40. To either confirm or disprove this suggestion, we developed a Sandwich ELISA approach, in which the wells of immunoplates were coated with the antibody against the whole extracellular domain (1-208) of a7 nAChR subunit, while the captured antigen was revealed with $\alpha 7(179-190)$-specific, IgM-specific or CD40-specific antibodies. The preparations of normal B lymphocytes, SP-2/0 hybridoma cells or mouse brain were used as the source of antigens. In the brain, lacking both IgM and CD40, the captured antigen was detected with $\alpha 7$-specific antibody only. In SP-2 cells, expressing CD40 but lacking $\operatorname{IgM}$, the antigen was detected with either $\alpha 7$-specific or CD40-specific second antibody. In B lymphocytes, the captured antigen was detected with all three antibodies suggesting that the nAChRs were coupled to both IgM and CD40. The whole extracellular domain 1-208 is quite homologous in different alpha subunits; therefore, we could expect that $\alpha 7(1-208)$-specific antibody bound any nAChR subtype present within the cell lysate. To reveal what $\mathrm{nAChR}$ subtypes are cou- 
pled to either IgM or CD40 in B lymphocytes, we applied a reverse assay, in which the plates were coated with either anti-IgM or anti-CD40 and the bound antigen was revealed with the antibodies against $\alpha 4, \alpha 7$ or $\alpha 9$ nAChR subunits. The antigen captured with anti-IgM was revealed with anti- $\alpha 4$, whereas that captured with anti-CD40 was detected with anti- $\alpha 7$. This data clearly indicated that $\alpha 7$-containing $n A C h R s$ were coupled to CD40, while $\alpha 4 \beta 2$ nAChRs to the BCR. The $\alpha 9$ nAChRs were located close to CD40 but not coupled to it.

To assess the functions of $\alpha 4 \beta 2, \alpha 7$ and $\alpha 9$ nAChRs in B lymphocytes we studied their proliferation in response to activation with either anti-CD40 or anti-IgM (F(ab)', fragments) in the presence or absence of $n A C h R$ subtype-specific ligands and in B lymphocytes of the wild-type, $\alpha 7-/-$ or $\beta 2-/-$ mice [18]. It was found that B lymphocytes of both $\alpha 7-/-$ and $\beta 2-/-$ mice responded to anti-CD40 stronger than those of the wild-type mice, whereas the cells of $\beta 2-/-$ mice responded to anti-IgM worse than those of the wild-type or $\alpha 7-/-$ mice. Inhibition of $\alpha 7$ and $\alpha 9$ nAChRs with methyllicaconitine (MLA) resulted in considerable augmentation of CD40-mediated B lymphocyte proliferation in cells of all genotypes; stimulation of $\alpha 4 \beta 2 \mathrm{nAChRs}$ with epibatidine increased the IgM-mediated proliferation of the wild-type and $\alpha 7-/-$, but not $\beta 2-/-$ cells. Inhibition of $\alpha 9$ nAChRs with $\alpha$-conotoxin PeAI exerted weak stimulating effect on CD40-mediated proliferation. It was concluded that $\alpha 7 \mathrm{nAChR}$ fulfills inhibitory CD40- related mitogenic function, $\alpha 4 \beta 2 \mathrm{nAChR}$ produces a stimulatory IgM-related effect, while $\alpha 9 \mathrm{nAChR}$ is a "reserve" receptor, which partly compensates the absence of $\alpha 7 \mathrm{nAChR}$ in $\alpha 7-/-$ cells (Fig. 1). In addition, the work of our Italian co-authors (Dr. A. Viola group from University of Milan, Italy) demonstrated that $\alpha 7 \mathrm{nAChRs}$ were recruited to immune synapse between human $\mathrm{T}$ and $\mathrm{B}$ lymphocytes, both of which produced acetylcholine. These data indicated that acetylcholine is an additional mediator to modulate activation of interacting $\mathrm{T}$ and B lymphocytes.

To reveal if acetylcholine produced by B lymphocytes exerts any effect on the strength of B lymphocyte activation we applied the inhibitors of acetylcholine esterase (piridostigmin, proserin and substance 547), kindly provided by Prof. E. Nikolsky from Kazan State University, Russian Federation. It was found that inhibiting acetylcholine degradation resulted in the decrease in B lymphocyte proliferation stimulated by anti-CD 40 . Conversely, application of hemicholine-3, which inhibits acetylcholine formation, increased B lymphocyte proliferation [23]. These data clearly demonstrated that endogenous acetylcholine produced by $\mathrm{B}$ lymphocytes (the assays were performed in purified B lymphocytes sorted out from the mouse spleen by magnetic procedure) is a negative regulator of their activation.

B lymphocytes are mediators of humoral immunity producing antibodies against invading pathogens. To reveal if the $\mathrm{nAChRs}$ are involved in regulating the antibody production by normal $\mathrm{B}$

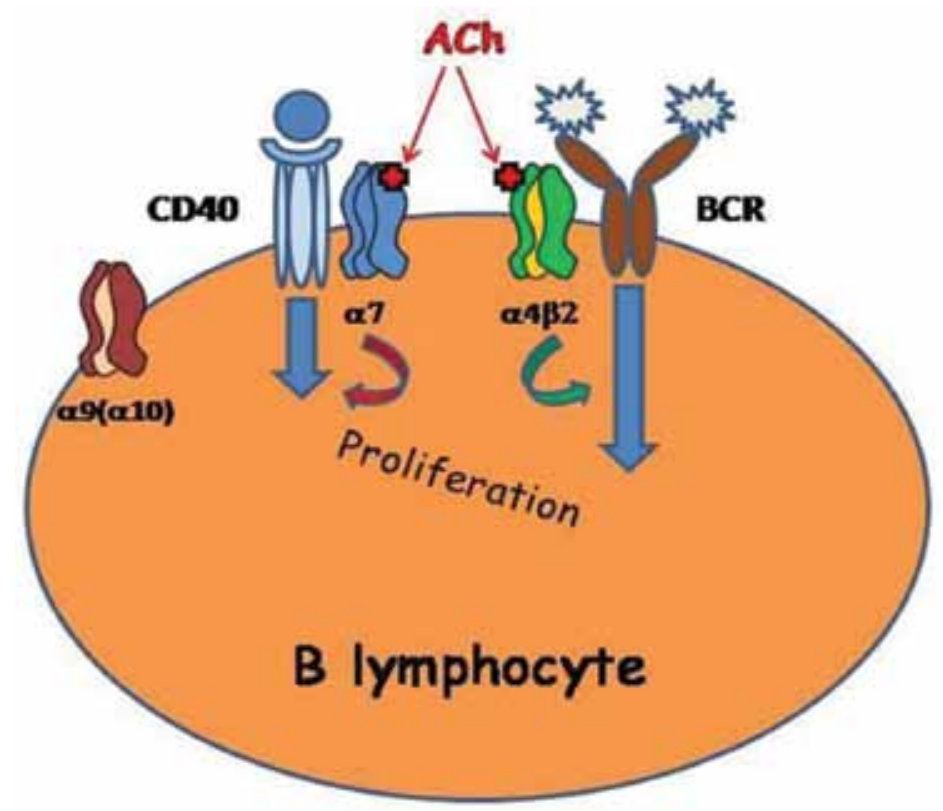

Fig. 1. The scheme of $n A C h R$ subtypes localization and functioning in B lymphocytes 
lymphocytes we applied several in vitro and in vivo approaches.

Mice lacking nicotinic receptor subunits $\alpha 4$, $\beta 2$ or $\alpha 7$ had less serum IgG and IgG-producing cells in the spleen, whereas the numbers of IgMproducing cells and the levels of serum IgM were similar to those in the wild-type mice. Knockout mice also had less antibodies against "natural" antigens like myosin or tubulin [22]. These data indicated that the lack of either $\alpha 4 \beta 2$ or $\alpha 7 \mathrm{nAChR}$ subtypes resulted in the narrowing of B lymphocyte antigen-specific repertoire and, therefore, nicotinic receptors were needed to keep the broad spectrum of antibody specificities. In contrast, mature B lymphocytes of mice lacking $\alpha 4, \beta 2$ or $\alpha 7$ nAChR subunits showed stronger IgG response to protein antigen in vivo than the wild-type mice that was in accord with the negative regulatory role of acetylcholine discussed above. Wild-type C57Bl/6 mice, when immunized with bovine cytochrome $c$ (cyt $c$ ) together with $\alpha 7$-specific inhibitor MLA, demonstrated faster and stronger primary IgM response than mice immunized with cyt $c$ alone, but no difference in the secondary IgG response [23]. Consequently, B lymphocytes stimulated with antiCD40 in vitro in the presence or absence of MLA did not show any difference in the $\operatorname{IgG}$ to $\operatorname{IgM}$ ratio [18]. It was concluded that the presence of (signaling through) nAChRs positively influenced the initial numbers of antigen-specific B lymphocytes but negatively regulated their response to protein antigens and had no effect on the IgM to $\mathrm{IgG}$ switch in the course of immune response.

Special efforts have been and are still being applied to reveal the mechanism of nAChR functioning in B lymphocytes. Preliminary data obtained in collaboration with Prof. O. Lukyanetz from Bogomoletz Institute of Physiology, Kyiv and Prof. P. Bregestovsky from Aix-Marseille University suggest that $\alpha 7 \mathrm{nAChRs}$ expressed in B lymphocytes do not function as classical ion channels, but rather influence signaling of adjacent receptors or initiate separate signaling pathways through conformational perturbations of the nAChR pentamer caused by either agonist or competitive antagonist binding.

\section{Structure and functions \\ of $\mathrm{nAChRs}$ in mitochondria}

The data obtained demonstrated a crucial role of nAChRs for the humoral immunity. Our further efforts were directed to elucidate the cellular mechanisms underlying the observed effects. Staining with Annexin V and propidium iodide revealed that the bone marrows of $\alpha 7-/-$ mice contained more apoptotic B lymphocyte precur- sors than those of the wild-type mice [19]. Additional experiments performed with the cells of pre-B lymphocyte-derived chicken DT40 cell line indicated that $\alpha 7$-specific agonist choline improved the survival of these cells under the effect of $\mathrm{H}_{2} \mathrm{O}_{2}$, and its positive influence was prevented by MLA [25]. This data attracted our attention to the role of $\alpha 7 \mathrm{nAChRs}$ in the cell survival. The $\alpha 7 \mathrm{nAChRs}$ expressed on the plasma membrane were shown to stimulate pro-survival signaling pathways in various types of cells $[7,26]$. Since $\mathrm{H}_{2} \mathrm{O}_{2}$ is considered to cause apoptosis by affecting mitochondria, we initiated experiments to reveal the possible involvement of nAChRs in mitochondria functioning.

The presence of nicotinic receptors in mitochondria has initially been discussed in connection with the neuroprotective role of nicotine. Then it was shown that nicotine affected mitochondria respiratory chain independent of nAChRs [27]. However, in other studies, the decrease of mitochondria membrane potential caused by ethanol was prevented with specific $\alpha 7 \mathrm{nAChR}$ agonist 2,4-dimethoxibenziliden anabasein, and this effect was blocked with MLA [28]. By studying isolated mouse liver mitochondria we demonstrated that functional a7 nAChRs, which had been previously found exclusively on the cell plasma membrane, were expressed in mitochondria outer membrane and regulated early pro-apoptotic events like cyt $c$ release [29]. The binding of $\alpha 7$-specific antibody with mouse liver mitochondria was demonstrated by electron microscopy. Outer membranes of mitochondria from the wild-type and $\beta 2-/-$ but not $\alpha 7-/-$ mice bound $\alpha 7 \mathrm{nAChR}$-specific antibody and toxins: FITC-labeled $\alpha$-cobratoxin or Alexa 555 -labeled $\alpha$-bungarotoxin. Here we applied the two versions of sandwich assays where the $\mathrm{nAChRs}$ were captured from the mitochondria membrane preparation with the $\alpha 7(1-208)$-specific antibody, while the bound antigen was revealed with either an $\alpha 7(179-190)$-specific antibody or $\alpha 7$-specific toxin. This work was performed in collaboration with the laboratory of Prof. V. Tsetlin (ShemyakinOvchinnikov Institute of Bioorganic Chemistry, Moscow). $\alpha 7 \mathrm{nAChR}$ agonists (acetylcholine, choline or PNU-282987) impaired intramitochondrial $\mathrm{Ca}^{2+}$ accumulation and significantly decreased cyt $c$ release stimulated with either $90 \mu \mathrm{M} \mathrm{CaCl}_{2}$ or $0.5 \mathrm{mM} \mathrm{H} \mathrm{O}_{2}$. The effect of agonists was similar to that of inhibitor of voltage-dependent anion channels (VDAC), and VDAC was co-captured with the $\alpha 7 \mathrm{nAChR}$ from mitochondria outer membrane preparation in sandwich ELISA. It was concluded that $\alpha 7 \mathrm{nAChRs}$ are expressed in mitochondria outer membrane to regulate the VDAC-mediated $\mathrm{Ca}^{2+}$ transport and mitochondrial permeability 
transition [29]. Similarly to $\alpha 7 \mathrm{nAChRs}$ expressed in B lymphocytes, those found in mitochondria seemed not to function as classical ion channels, but to influence the adjacent proteins like VDAC through conformational perturbations caused by the binding of either agonist or antagonist molecule (Fig. 2). This data indicated that, in addition to established anti-apoptotic signaling pathways mediated by plasma membrane $\alpha 7 \mathrm{nAChRs}$, there is an endogenous, previously unrecognized cholinergic mechanism to control mitochondria functions and their apoptotic susceptibility.

The presence of $\alpha 7 \mathrm{nAChRs}$ in mitochondria was further confirmed by confocal microscopy studies performed with several human cell lines [30].

The results of subsequent studies, which are now being prepared for publication, demonstrate that anti-apoptotic functioning of $\alpha 7 \mathrm{nAChRs}$ in mitochondria involves activation of intramitochondrial kinases, first of all, of PI3K/Akt pathway. Moreover, it now becomes evident that $\alpha 7$ is not the only nAChR subtype expressed in mitochondria; others like $\alpha 3 \beta 2$ and $\alpha 4 \beta 2$ were also found and were demonstrated to maintain mitochondrial integrity similarly to $\alpha 7 \mathrm{nAChR}$ subtype. Taken together, these findings offer a novel view on the mitochondria protection in apoptosis and open the way for its pharmacological regulation.

Functional effects of nAChR-specific antibodies and their possible involvement in the development of neurodegenerative disorders like Alzheimer disease

Autoantibodies against $\mathrm{nAChRs}$ found in neuro-muscular junctions are the main cause of autoimmune Myasthenia gravis [11]. Antibodies against neuronal $\mathrm{nAChR}$ subtypes have been found upon several forms of gangliopathy [31]. The brain has been for a long time considered defended from immune attacks by the blood-brain barrier. However, more and more data indicate that this defense is not absolute, and the antibodies and even lymphocytes can penetrate the brain upon pathological conditions.

Alzheimer disease (AD) is a neurodegenerative pathology, which develops in elderly people as a form of dementia accompanied by the impairments of memory, space orientation, speaking and practical habits. Pathogenesis of AD is characterized by the appearance of aberrant forms of betaamyloid (A $\beta$ 1-42) producing extracellular insoluble inclusions ("plaques"). It is also accompanied

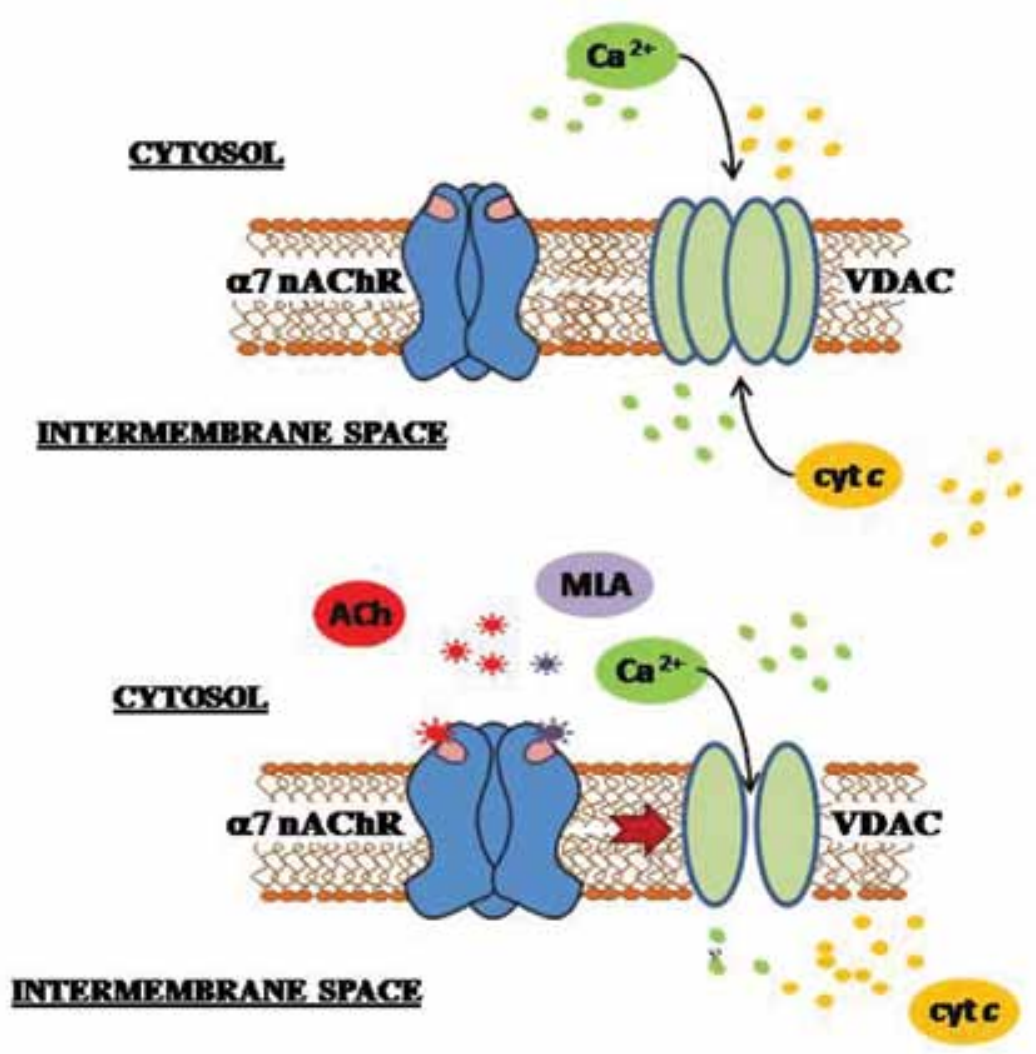

Fig. 2. The scheme of $\alpha 7 n A C h R$ localization and functioning in the outer membrane of mitochondria 
with the cholinergic deficit and the loss of $\alpha 4 \beta 2$ and $\alpha 7$ nicotinic acetylcholine receptors (nAChRs) in the brain neurons [32]. However, the exact reasons for this loss were not completely understood. We hypothesized that a reduction of nAChRs in the brain might be due to immune mechanism involving $\mathrm{nAChR}$-specific autoantibodies.

To test this we either immunized mice with an extracellular domain of $\alpha 7 \mathrm{nAChR}$ subunit ( $\alpha 7(1-208))$ or injected them with $\alpha 7(1-208)$-specific antibodies generated in rabbits and examined the density of nAChRs both in peripheral tissues and within the brain, as well as the functional consequences of immunization/antibody injection. The recombinant $\alpha 7(1-208)$ domain was produced in the laboratory of Prof. S. Tzartos from Hellenic Pasteur Institute in Athens. It was found that injected $\alpha 7(1-208)$-specific antibodies decreased the a7 nAChR density on mouse B lymphocytes and the numbers of Annexin V-positive B lymphocytes in the spleen. Immunization of mice with a7(1-208) resulted in connective tissue overgrowth and infiltration of segmented neutrophils in the spleen (studied with the help of Dr. S. Pavlovich from Bogomoletz Institute of Physiology, Kyiv), as well as in decreased body weight compared to mice immunized with BSA. It was concluded that $\alpha 7$ nAChR-specific antibodies were functionally active regulating the lymphocyte survival, neutrophil migration, connective tissue growth and body weight (Fig. 3, lower part) [33].
Further studies demonstrated that $\alpha 7(1-208)-$ specific antibodies were able to cross the bloodbrain barrier to decrease the $\alpha 7 \mathrm{nAChR}$ density in certain brain regions of mice. Antibody injection resulted in brain $\mathrm{nAChR}$ decrease only if mice were co-injected with bacterial lipopolysaccharide. Brain sections of immunized mice were analyzed for the binding of $\left[{ }^{125} \mathrm{I}\right]-\alpha$-bungarotoxin and $\left[{ }^{125} \mathrm{I}\right]-$ epibatidine. A decrease in $\alpha$-bungarotoxin binding in striatum (nucleus accumbens and caudate putamen) accompanied with an increase of epibatidine binding in the forebrain and caudate putamen was observed in mice immunized with $\alpha 7 \mathrm{nAChR}$ domain compared to those immunized with BSA. Mice immunized with a7(1-208) demonstrated significantly worse episodic memory compared to non-immunized animals but did not differ from the controls in locomotor or anxiety-related tests. These results showed that nAChR-specific antibodies penetrating the brain upon induced inflammation caused a decrease of brain $\alpha 7 \mathrm{nAChRs}$ and worsened the memory behavior of immunized mice. These experiments were performed in collaboration with Dr. I. Cloez-Tayarani and Dr. S. Granon from Pasteur Institute, Paris [34].

We further asked if the antibodies of similar specificity can be found in humans; if yes, what stimulates their production; and whether the presence of such antibodies is related to Alzheimer disease. For this purpose, we examined several groups of people including healthy individuals

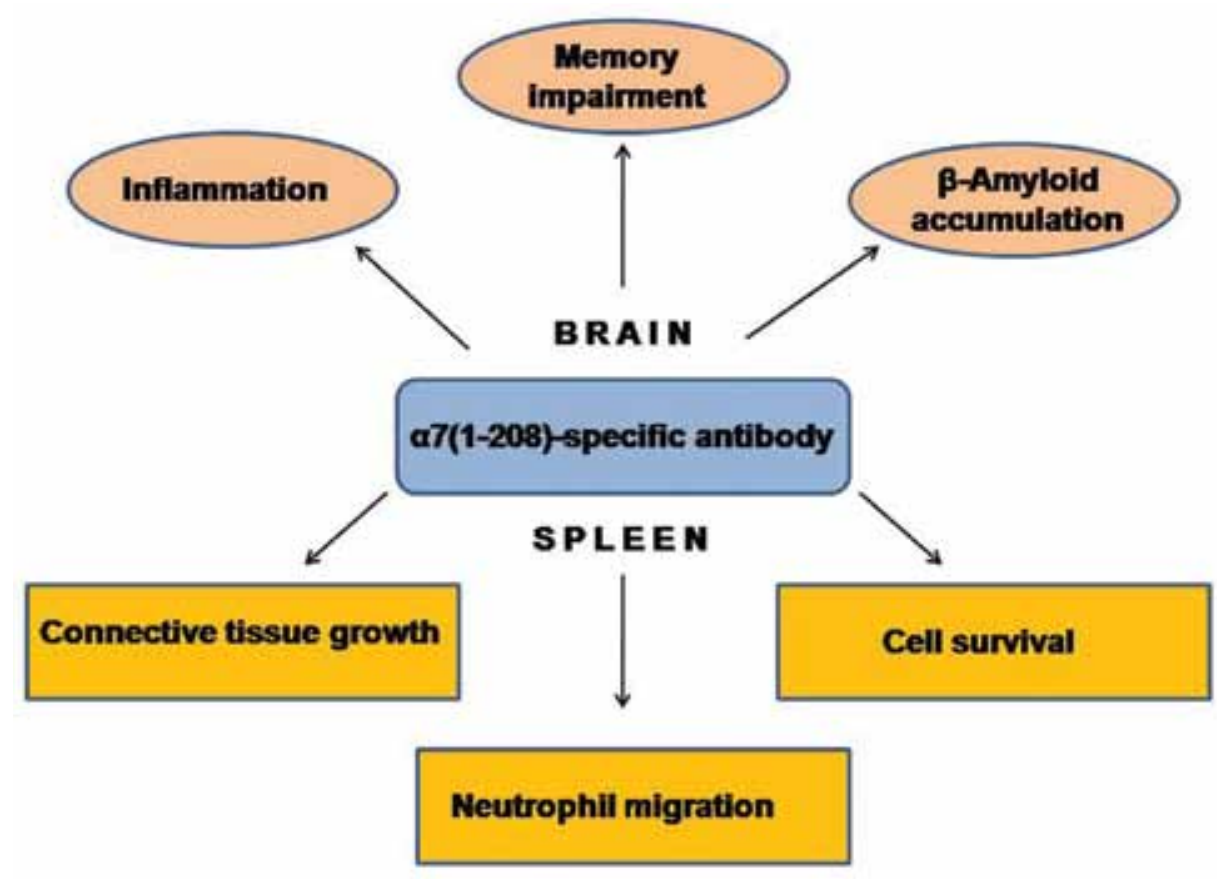

Fig. 3. The effects of $\alpha 7(1-208)$-specific antibody performed in the brain and spleen 
of various age, children suffering from respiratory diseases and Alzheimer patients with different forms of $\mathrm{AD}$. The blood samples were provided by Prof. S. Tzartos (Hellenic Pasteur Institute, Athens), Prof. N. Bachinskaya (Institute of Gerontology, Kyiv) and Mrs Hanna Kravtsova (Institute of Pediatry, Obstetrics and Gynecology, Kyiv). The antibodies capable to bind $\alpha 7(1-208)$ were found in the blood of both healthy humans and AD patients. In healthy individuals, their capacity to compete with $\left[{ }^{125}-\mathrm{I}\right]-\alpha$-bungarotoxin for the binding to $\alpha 7(1-208)$ increased with age. The level of such antibodies was significantly elevated in children with severe form of obstructive bronchitis. We also observed generation of such antibodies in mice injected with Lewis lung carcinoma cells expressing both $\alpha 4 \beta 2$ and $\alpha 7$ nAChRs. Among AD patients, the level of $\alpha 7 \mathrm{nAChR}$-specific antibodies was significantly higher in people $62.5 \pm 1.5$ years old with moderate or severe AD stages (15.2 \pm 1.3 MMSE scores) compared to those of $76 \pm 1.5$ years old with the mild (22.7 \pm 0.1 MMSE scores) AD stage. It was concluded that $\alpha 7(1-208) n A C h R-$ specific antibodies found in the human blood had been formed as a result of common infections accompanied with the destruction of respiratory epithelium. Elevated blood plasma levels of $\alpha 7(1-208)$ nAChR-specific antibodies were characteristic of the early-onset $\mathrm{AD}$ and, therefore, were suggested as one of the risk factors for the development of this form of the disease [35]. These experiments are now being continued to reveal if prolonged presence of $\alpha 7(1-208)$-specific antibodies in the brain can cause neurodegeneration and accumulation of abberantly processed $\beta$-amyloid, which was shown to be coupled to $\alpha 7$ nAChR. Preliminary yet unpublished data allow suggesting that $\alpha 7(1-$ 208)-specific antibodies cause redistribution of nAChR subtypes in the brain, affect susceptibility of brain mitochondria to apoptogenic stimuli and favor accumulation of $\beta$-amyloid both in the cells and mitochondria of the brain. Additional experiments performed in human glioblastoma U373 cell line demonstrated that antibodies specific to the extracellular epitope of $\alpha 7 \mathrm{nAChR}$ subunit stimulated production of interleukin- 6 and, therefore, could be regarded as pro-inflammatory agents for the brain astrocytes.

Taken together, the results obtained clearly demonstrated that $\alpha 7$-specific antibodies were physiologically active and could both influence the level of corresponding nAChRs expressed on the cell surface and stimulate intracellular processes favoring local neuroinflammation and $\beta$-amyloid accumulation (Fig. 3, upper part).

In conclusion, experiments performed in our group during the last decade revealed that $\mathrm{nAChRs}$ play an important role in humoral immunity. Being expressed in B lymphocytes, they regulate both the formation of their antigen-specific repertoire in the course of development and activation in mature state. Different $\mathrm{nAChR}$ subtypes are present along with the B lymphocyte maturation: $\alpha 4 \beta 2 \mathrm{nAChRs}$ are prevalent in immature B lymphocytes within the bone marrow, while $\alpha 7 \mathrm{nAChRs}$ are mostly found in mature B lymphocytes in the spleen. Possibly, this difference corresponds to different kinds of nAChR agonists present in the primary vs secondary lymphoid organs. The bone marrow is innervated with cholinergic nerve fibers; therefore, differentiation of the blood cells can be regulated with neuronal acetylcholine through $\alpha 4 \beta 2 \mathrm{nAChRs}$ sensitive to nanomolar doses of this agonist. In contrast, the spleen has no cholinergic innervation; therefore, the nAChRs expressed in mature B lymphocytes can be stimulated (or desensitized) either by choline, which is an $\alpha 7$-specific agonist, or by acetylcholine produced by activated $\mathrm{T}$ and $B$ lymphocytes and affecting them locally within the immune synapse. $\alpha 4 \beta 2 \mathrm{nAChRs}$ are localized in close proximity to the antigen-specific receptor (BCR) and positively regulate its involvement in B lymphocyte differentiation. $\alpha 7 \mathrm{nAChRs}$ are located close to CD40 and negatively regulate its signaling in the course of B lymphocyte activation. $\alpha 9$ nAChRs comprise a minor population capable of fulfilling functions similar to those of $\alpha 7 \mathrm{nAChRs}$ and partially substitute them in $\alpha 7-/-$ animals. On the whole, the data obtained delineate the role of cholinergic mechanisms in humoral immunity underlying the observed immunosuppression in smokers constantly consuming $\mathrm{nAChR}$ agonist nicotine.

One of the ways through which the nAChRs are involved in B lymphocyte differentiation is the support of cell survival. Our data have revealed that, in addition to established pro-survival signaling pathway starting from a plasma membrane $\alpha 7 \mathrm{nAChR}$, there is an intracellular pathway engaging the $\mathrm{nAChRs}$ expressed in mitochondria outer membrane. This is the first example of functional nAChRs expressed in the intracellular organelles. Possibly, it belongs to the most ancient survival mechanisms inherited by mitochondria from their hypothetic prokaryotic ancestor. This novel finding raises a lot of questions concerning the mechanisms of the $\mathrm{nAChR}$ targeting to and functioning in mitochondria that is the subject of ongoing studies.

Finally, we have found that antibodies raised against extracellular portions of $\mathrm{nAChR}$ subunits are not only reliable tools to study the nAChR exposure on the cells or mitochondria, but play a significant physiological role in vivo. Most im- 
portantly, they are able to penetrate the brain and to impair memory with subsequent loss of brain $\alpha 7 \mathrm{nAChRs}$ and accumulation of $\beta$-amyloid. The documented presence of such antibodies in humans and their relation to the early-onset AD suggests a pronounced immunological component in pathogenesis of $\mathrm{AD}$.

\section{НІКОТИНОВІ АЦЕТИЛХОЛІНОВІ РЕЦЕПТОРИ: СПЕЦИФІЧНІ АНТИТІЛА І ФУНКЦІЇ В ГУМОРАЛЬНОМУ ІМУНІТЕТІ}
М. В. Скок, Л. М. Коваль, О. Ю. Лихмус,
О. М. Калашник, Г. Л. Гергалова,
C. В. Комісаренко

\author{
Інститут біохімії ім. О. В. Палладіна \\ НАН України, Київ; \\ e-mail: skok@biochem.kiev.ua
}

Нікотинові ацетилхолінові рецептори (нАХР) - це лігандзалежні іонні канали, спочатку відкриті у м'язах та нейронах і у подальшому винайдені в багатьох незбудливих клітинах. В огляді підсумовано результати досліджень, які було проведено у відділі молекулярної імунології протягом останніх десяти років, що стосуються будови і функцій нАХР у В-лімфоцитах і мітохондріях, а також ролі нАХР-специфічних антитіл у розвитку нейродегенеративних захворювань, таких як хвороба Альцгеймера.

К л ючов і слов а: нікотиновий ацетилхоліновий рецептор, В-лімфоцити, мітохондрії, антитіла, хвороба Альцгеймера.

\section{НИКОТИНОВЫЕ \\ АЦЕТИЛХОЛИНОВЫЕ РЕЦЕПТОРЫ: СПЕЦИФИЧНЫЕ АНТИТЕЛА И ФУНКЦИИ В ГУМОРАЛЬНОМ ИММУНИТЕТЕ}
М. В. Скок, Л. Н. Коваль, Е. Ю. Лихмус,
Е. Н. Калашник, Г. Л. Гергалова,
С. В. Комисаренко
Институт биохимии им. А. В. Палладина НАН Украины, Киев; e-mail: skok@biochem.kiev.ua

Никотиновые ацетилхолиновые рецепторы (нАХР) - это лигандзависимые ионные каналы, первоначально открытые в мышцах и нейронах и в дальнейшем найденные во многих невозбудимых клетках. В обзоре суммированы результаты исследований, которые были проведены в отделе молекулярной иммуно- логии на протяжении последних десяти лет, касающиеся структуры и функций нАХР в В-лимфоцитах и митохондриях, а также роли нАХР-специфичных антител в развитии нейродегенеративных заболеваний, таких как болезнь Альцгеймера.

Кл ючевы е слова: никотиновый ацетилхолиновый рецептор, В-лимфоциты, митохондрии, антитела, болезнь Альцгеймера.

1. Bamel K., Gupta S. C., Gupta R. // Life Sci. 2007. - 80. - P. 2393-2396.

2. Kawashima K., Fujii T. // J. Pharmacol. Sci. 2008. - 106. - P. 167-173.

3. Kummer W., Lips K. S., Pfeil U. // Histochem. Cell Biol. - 2008. - 130. - P. 219-234.

4. Bocquet N., Prado de Carvalho L., Cartaud J. et al. // Nature. - 2007. - 445. - P. 116-119.

5. Changeux J. P. // J. Biol. Chem. - 2012. 287. - P. 40207-40215.

6. Albuquerque E. X., Pereira E. F., Alkondon M., Rogers S. W. // Physiol. Rev. - 2009. - 89. P. $73-120$.

7. Parada E., Egea J., Romero A. et al. // Free Radic. Biol. Med. - 2010. - 49. - P. 18151821.

8. Chernyavsky A. I., Arredondo J., Marubio L. M., Grando S. A. // J. Cell. Sci. - 2004. - 117. P. 5665-5679.

9. Arias H. R., Richards V. E., Ng D. et al. // Int. J. Biochem. Cell. Biol. - 2009. - 41. P. 1441-1451.

10. Filippini P., Cesario A., Fini M. et al. // Curr. Drug Targets. - 2012. - 13. - P. 644-655.

11. Lindstrom J. M. // Muscle Nerve. - 2000. 23. - P. 453-477.

12. Wakkach A., Guyon T., Bruand C. et al. // J. Immunol. - 1996. - 157. - P. 3752-3760.

13. Holt P.G., Keast D. // Bacteriol. Rev. - 1977. 41. - P. 205-216.

14. Skok M. V., Voitenko L. P., Voitenko S. V. // Neuroscience. - 1999. - 93. - P. 1437-1446.

15. Koval O. M., Voitenko L. P., Skok M. V. et al. // Neurosci. Lett. - 2004. - 365. - P. 143-146.

16. Shelukhina I. V., Kryukova E. V., Skok M. V. et al. // Biochemistry (Moscow). - 2006. - 71. P. 744-758.

17. Skok M., Lykhmus E., Bobrovnik S. et al. // J. Neuroimmunol. - 2001 - 121. - P. 59-66.

18. Koval L., Lykhmus O., Zhmak M. et al. // Int. J. Biochem. Cell Biol. - 2011. - 43. - P. 516-524.

19. Skok M. V., Grailhe R., Agenes F., Changeux J.-P. // J. Neuroimmunol. - 2006. - 171. - P. 86-98.

20. Коваль Л. М., Романюк С. І., Колибо Д. В. та ін. // Укр. біохім. журн. - 2005. - 77, № 2. - P. 105-111. 
21. Skok M. V., Kalashnik E. N., Koval L. N. et al. // Mol. Pharmacol. - 2003. - 64. - P. 885889.

22. Skok M. V., Grailhe R., Changeux J.-P. // Eur. J. Pharmacol. - 2005. - 517. - P. 246-251.

23. Koval L. M., Lykhmus O. Yu., Omelchenko D. M. et al. // Ukr. Biochim. Zh. - 2009. - 81, N 4. - P. 5-11.

24. Koval L. M., Zverkova A. S., Grailhe R. et al. // Int. J. Biochem. Cell Biol. - 2008. - 40. P. 980-990.

25. Омельченко Д. М., Калашник О. М., Коваль Л. М. та ін. // Ukr. Biochim. Zh. 2009. - 81, N 1. - P. 59-66.

26. Parada E., Egea J., Romero A. et al. // Free Radic. Biol. Med. - 2010. - 49. - P. 18151821.

27. Cormier A., Morin C., Zini R. // Brain Res. 2001. - 900. - P. 72-79.
28. Li Y., Meyer E. M., Walker D. W. et al. // J. Neurochem. - 2002. - 81. - P. 853-858.

29. Gergalova G. L., Lykhmus O. Yu., Kalashnyk O. M. et al. // PLoS ONE. - 2012. - 7. e31361.

30. Kalashnyk O. M., Gergalova G. L., Komisarenko S. V., Skok M. V. // Life Sci. - 2012. 91. - P. 1033-1037.

31. Winston N., Vernino S. // Curr. Opin. Neurol. 2010. - 23. - P. 514-518.

32. Hellstrom-Lindahl E., Mousavi M., Zhang X. et al. // Mol. Brain Res. - 1999. - 66. - P. 94-103.

33. Lykhmus O., Koval L., Pavlovych S. et al. // Immunology Letters. - 2010. - 128. - P. 68-73.

34. Lykhmus O. Yu., Koval L. M., Skok M. V. et al. // J. Alz. Dis. - 2011. - 24. - P. 693-704.

35. Koval L., Lykhmus O., Kalashnyk O. et al. // J. Alz. Dis. - 2011. - 25. - P. 747-761. 